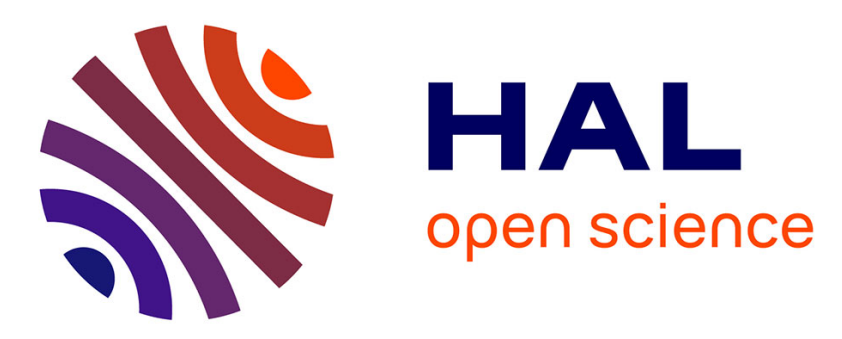

\title{
Testicular innate immune defense against bacteria
} Sudhanshu Bhushan, Hans-Christian Schuppe, Svetlin Tchatalbachev, Monika Fijak, Wolfgang Weidner, Trinad Chakraborty, Andreas Meinhardt

\section{To cite this version:}

Sudhanshu Bhushan, Hans-Christian Schuppe, Svetlin Tchatalbachev, Monika Fijak, Wolfgang Weidner, et al.. Testicular innate immune defense against bacteria. Molecular and Cellular Endocrinology, 2009, 306 (1-2), pp.37. 10.1016/j.mce.2008.10.017 . hal-00532100

\section{HAL Id: hal-00532100 https://hal.science/hal-00532100}

Submitted on 4 Nov 2010

HAL is a multi-disciplinary open access archive for the deposit and dissemination of scientific research documents, whether they are published or not. The documents may come from teaching and research institutions in France or abroad, or from public or private research centers.
L'archive ouverte pluridisciplinaire HAL, est destinée au dépôt et à la diffusion de documents scientifiques de niveau recherche, publiés ou non, émanant des établissements d'enseignement et de recherche français ou étrangers, des laboratoires publics ou privés. 


\section{Accepted Manuscript}

Title: Testicular innate immune defense against bacteria

Authors: Sudhanshu Bhushan, Hans-Christian Schuppe, Svetlin Tchatalbachev, Monika Fijak, Wolfgang Weidner, Trinad Chakraborty, Andreas Meinhardt

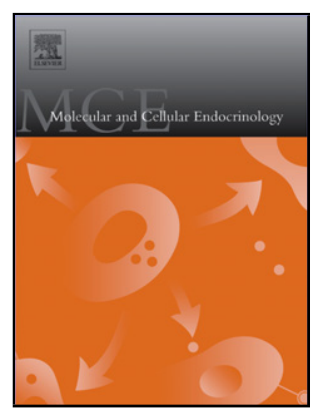

PII:

S0303-7207(08)00458-9

DOI: doi:10.1016/j.mce.2008.10.017

Reference: MCE 7017

To appear in: $\quad$ Molecular and Cellular Endocrinology

Received date: $\quad 31-7-2008$

Revised date: 2-10-2008

Accepted date: $\quad 3-10-2008$

Please cite this article as: Bhushan, S., Schuppe, H.-C., Tchatalbachev, S., Fijak, M., Weidner, W., Chakraborty, T., Meinhardt, A., Testicular innate immune defense against bacteria, Molecular and Cellular Endocrinology (2008), doi:10.1016/j.mce.2008.10.017

This is a PDF file of an unedited manuscript that has been accepted for publication. As a service to our customers we are providing this early version of the manuscript. The manuscript will undergo copyediting, typesetting, and review of the resulting proof before it is published in its final form. Please note that during the production process errors may be discovered which could affect the content, and all legal disclaimers that apply to the journal pertain. 


\section{Testicular innate immune defense against bacteria}

Sudhanshu Bhushan, Hans-Christian Schuppe , Svetlin Tchatalbachev $^{\S}$, Monika Fijak, Wolfgang Weidner ${ }^{\Phi}$, Trinad Chakraborty ${ }^{\S}$, Andreas Meinhardt*

Department of Anatomy and Cell Biology, Unit of Reproductive Biology, ${ }^{\#}$ Centre of Dermatology and Andrology, ${ }^{\S}$ Department of Medical Microbiology, ${ }^{\Phi}$ Clinic of Urology and Pediatric Urology, Justus-Liebig-University of Giessen, Germany.

*Corresponding author: $\quad$ Prof. Dr. Andreas Meinhardt, $\mathrm{PhD}$

Department of Anatomy and Cell Biology

Justus-Liebig-University of Giessen

Aulweg 123

35385 Giessen, Germany

Phone: +49-641-9947024

Fax: +49-641-9947029

E-mail: andreas.meinhardt@ anatomie.med.uni-giessen.de 


\begin{abstract}
Infection and inflammation are relevant entities of male factor infertility. Bacterial infections are mostly the consequence of an ascending infection of the genito-urinary tract which can ultimately lead to epididymo-orchitis. Bacterial toxins and the innate immune responses directed against them may have a significant impact on male reproductive function. Toll-like receptors (TLRs) constitute the major family of pattern recognition receptors that play a pivotal role in innate immunity. In the testis, TLRs are not only found in immune cells such as macrophages and dendritic cells, but also in testicular somatic cells and to a lesser extent in germ cells. In this review we describe relevant bacterial pathogens found in testicular and male reproductive tract infection, new data on the localisation and potential functions of TLRs, recognition and response to bacteria with a special emphasis on uropathogenic E. coli. Mechanisms by which uropathogenic E. coli subvert innate immune responses in the testis are discussed using information derived from animal model studies.
\end{abstract}




\section{Relevant pathogens causing testicular dysfunction}

Following some controversy in the past it is now accepted that bacterial and viral infections of the male reproductive tract contribute significantly to impaired fertility. Bacterial infection of the male genital tract often results from ascending canalicular infections of the male excurrent ducts and can manifest itself as urethritis, prostatitis/vesiculitis, epididymitis or epididymo-orchitis. Bacteria eliciting epididymoorchitis are either sexually transmitted or originate from urinary tract infections (Purvis \& Christiansen, 1993; Weidner et al., 1999; Anders \& Patole, 2005; Ludwig, 2008). Among sexually active men younger than 35 years with a medical history of urethral discharge, the most prevalent pathogens related to epididymo-orchitis are Chlamydia trachomatis and Neisseria gonorrhoeae (Weidner et al., 1999; Ludwig, 2008; Ochsendorf, 2008). Apart from sexually transmitted infections, the most common cause for epididymoorchitis is genito-urinary tract infection with E. coli and other Enterobacteriaceae especially in older men. Uropathogenic Escherichia coli (UPEC) are among the most frequently isolated microbial agents in urinary tract infections, whereas in semen the subtype of E. coli is rarely specified (Wiles et al., 2008).

Bacterial epididymo-orchitis represents a relevant clinical entity in andrology and urology. A prevalence of 600,000 cases of acute epididymitis per year has been reported in the USA (Krieger, 1984). According to Collins et al. (Collins et al., 1998) epididymitis/orchitis accounted for $0.30 \%$ of all consultations to office-based physicians of all specialties in the USA, and was ranked fifth among genitourinary diagnoses in those aged 18-50 years. In a recent urological outpatient study, epididymitis accounted for approximately $1 \%$ of visits, with $80 \%$ of these patients having symptoms longer than 3 months (Nickel et al., 2002). Inflammation of the testis as a complication of acute epididymitis due to ascending, canalicular bacterial infections is common and may occur in up to $60 \%$ of affected patients (Ludwig et al., 2008; Schuppe et al., 2008). Of note, whereas acute testicular inflammation is symptomatic, most patients with subacute or chronic impairment are asymptomatic (Schuppe et al., 2008). Treatment of the acute phase of disease, i.e. bacterial epididymo-orchitis, is based on antibiotic and antiphlogistic pharmacotherapy (Weidner et al., 2002). Even after successful intervention, however, the inflammatory reaction can chronify silently in both testes with major 
functional and structural damage of the seminiferous tubules and subsequent infertility (Weidner et al., 1990; Osegbe, 1991; Fijak \& Meinhardt, 2006; Schuppe et al., 2008). Hence, it is almost certain that genital tract inflammation/infection including the chronic form contributes to a larger extent to the cohort of patients with "idiopathic" infertility (Schuppe \& Meinhardt, 2005; Haidl et al., 2008). Until now, however, the clinical identification of chronic genital tract inflammation/infection has been hampered by the lack of symptoms and non-invasive diagnostic tools.

\section{Uropathogenic $E$. coli}

E. coli, the most common facultative gram negative bacteria in the human fecal flora, usually resides in the colon as a harmless commensal. From a clinical point of view, $E$. coli of biological importance to humans can be broadly classified as (1) commensal $E$. coli (i.e. intestinal colonizers), (2) intestinal pathogenic E. coli (i.e. enteric or diarrheagenic strains), and (3) extraintestinal pathogenic E. coli (ExPEC) (Russo \& Johnson, 2000). E. coli is a highly clonal species represented by 4 major phylogenetic groups comprising A, B1, B2 and D (Johnson \& Russo, 2005). Diarrheagenic E. coli occur almost exclusively in A, B1 and D as well as other ungrouped phylogenetic groups, while uropathogenic and other extraintestinal E. coli are present within the B2 group. Uropathogenic Escherichia coli (UPEC) are the most frequent cause of urinary tract infection and are responsible for $70-90 \%$ of the anticipated 150 million urinary tract infections diagnosed annually (Stamm \& Norrby, 2001). UPEC have acquired specific virulence attributes such as adhesins, $\alpha$-haemolysin, siderophores and polysaccharide coatings (Eisenstein \& Jones, 1988; Johnson, 1991; Johnson \& Kuskowski, 2000; Johnson \& Stell, 2000; Russo \& Johnson, 2000). These factors confer upon UPEC the ability to avoid or subvert host defenses, colonize and invade host tissue, perturb host physiology, invade host tissues, and/or aggravate a deleterious host inflammatory response, thereby causing disease (Russo \& Johnson, 2000). These UPEC virulence factors are usually encoded on the chromosome of UPEC and are often part of large, unstable chromosomal regions, known as pathogenic islands (PAIs) (Blum et al., 1994; Swenson et al., 1996; Hacker et al., 2003; Dobrindt et al., 2004). Currently nine PAIs have been described, but the majority of virulence determinants are located on only five 
PAIs. Indeed, all virulent factors such as toxins, adhesins, an ion siderophore system, proteases, capsule and LPS are expressed on five PAIs present in UPEC CFT073 strain. The role in pathogenicity of these PAIs have been tested in a murine model. Mutational analyses of these PAIs have shown that deletion of a single PAI did not significantly affect the survival of infected mice. Deletions comprising two or three PAIs, however, significantly reduced the virulence potential of these strains (Brzuszkiewicz et al., 2006).

The two UPEC strains 536 and CFT073 have been completely sequenced and several of their PAIs have been studied in detail (Hacker et al., 1983; Mobley et al., 1990; Kao et al., 1997; Guyer et al., 1998; Rasko et al., 2001; Dobrindt et al., 2002; Schneider et al., 2004). The complete genome sequence analysis of UPEC strain CFT073 has revealed extensive mosaic structure in terms of the distribution of backbone gene conserved in E. coli, and "foreign" genes, which probably have been acquired horizontally (Welch et al., 2002). The genome E. coli strain CFT073 consists of a single circular chromosome of 5,231,428 bp and is 292 bp larger than that of strain 536.

\section{Testicular innate immunity and defense mechanisms to bacterial infection}

The excurrent ducts can provide a gateway for ascending microbial infections, which can manifest itself as urethritis, prostatitis, epididymitis or epididymo-orchitis. It is therefore not surprising that in $13-15 \%$ of all cases of male factor infertility infection and inflammation of the male genital tract are considered as primary cause or co-factor of fertility disturbances (WHO, 1987; Nieschlag \& Behre, 2000; Dohle et al., 2005). On the other hand, the testis is an immunologically privileged organ protecting the auto-antigens of the meiotic and haploid germ cells, which first appear after the establishment of selftolerance at the time of puberty (Head et al., 1983; Filippini et al., 2001; Hedger \& Meinhardt, 2003; Fijak \& Meinhardt, 2006). Immune privilege is attributed to tissues such as the eye, brain and fetal-maternal interface which prevent the spread of inflammation, because even minor incidences can threaten organ integrity and function (Girling \& Hedger, 2007). It is therefore somewhat paradoxical that microorganisms can disrupt immune privilege causing impairment of spermatogenesis. At the cellular level testicular macrophages in the interstitial space, Sertoli cells and to a lesser extent peritubular cells have been implicated in both the maintenance of immune privilege and a 
primary role in local inflammatory responses (Figure 1) (Fijak \& Meinhardt, 2006). The direct pathologic effects resulting from the bacterial invasion are often aggravated by the inflammatory process (Schuppe \& Meinhardt, 2005; Girling \& Hedger, 2007). Consequently it is important to understand the mechanisms by which immunocompetent cells in the testis recognize infectious agents and how bacterial pathogens try to diminish an inflammatory response by interfering with testicular defence pathways (Figure 1 and 2).

\section{Toll like receptors and innate immunity}

All living beings are exposed constantly to microbial agents that are present in nature and need to deal with the invasion of these organisms into the body. The reliable detection of microorganisms is a complex and daunting task because of their molecular heterogeneity and rapid evolution. All vertebrates have developed immune responses to protect against potential microbial invasion. The vertebrate immune response can be functionally divided into innate and adaptive immunity, with the innate immunity being the first line of defense against microorganisms. Adaptive immune responses are on the contrary slower responses mediated by $\mathrm{T}$ and $\mathrm{B}$ cells which express highly diverse antigen receptors. Innate immunity had been considered as a nonspecific system, and until recently less attention has been paid towards the abilities of this system to contain insults. However, the discovery of pattern recognition receptors, which detect pathogens through evolutionary conserved pathogens-associated-molecular-patterns has greatly advanced the concept of innate immunity. Toll-like receptors (TLRs) and intracellular nucleotide-binding oligomerization domain proteins are two classes of pathogen recognizing receptors involved in innate immune detection.

The discovery of the TLRs was initiated by the finding of Toll, a gene product essential for the development of embryonic dorsoventral polarity in drosophila (Hashimoto et al., 1988). Subsequent studies have revealed that Toll plays a critical role in the antifungal responses of flies (Lemaitre et al., 1996). So far, 13 different members of the TLR family have been identified through data base search in mammals (10 in humans and 12 in mice) (Akira \& Takeda, 2004; Beutler, 2004). TLR expression was found in various immune cells such as macrophages, dendritic cells, B cells, T cells, mast 
cells, monocytes, neutrophils, eosinophil and even on non immune cells such as fibroblast and epithelial cells (Applequist et al., 2002). Expression pattern of TLRs is not constant, but varies relatively quickly in response to the presence of their respective ligands. Among the characterized TLRs, TLR1, 2, 4, 5 and 6 are expressed on the cell surface and appear to exclusively identify bacterial and fungal components that are not made by the host, whereas TLR3, 7, 8 and 9, located in intracellular endosomes, specifically detect nucleic acids of pathogens (Akira et al., 2006).

The TLRs are type 1 integral membrane glycoproteins classified on the basis of considerable homology in the cytoplasmic domain to that of the interleukin type 1 receptor (IL-1R), termed the Toll/IL-1R homology domain (Bowie \& O'Neill, 2000). The cytoplasmic domain of TLRs and IL-1Rs have a conserved region of approximately 200 amino acids, which is known as the Toll/IL-1R (TIR) domain (Slack et al., 2000).

\section{Toll like receptor expression in the testis}

The innate defence of the testis like that of other organs hinges on recognition of bacterial products by members of the Toll-like receptor (TLR) family. In view of the paradox immune status of the testis with its obvious susceptibility for infection and inflammatory responses in an immune privileged environment (Fijak \& Meinhardt, 2006), it is surprising that only few studies have examined the role of TLRs in this organ thus far (Girling \& Hedger, 2007). It is only recently that expression of TLR 1-11 was shown in total rat testis, epididymis and vas deferens (Palladino et al., 2007) and of TLR 1-9 in human testis samples (Nishimura \& Naito, 2005). Riccioli et al. (Riccioli et al., 2006) reported expression of TLR 2-6 mRNA in mouse Sertoli cells. Stimulation of TLR2, 3 and TLR5 by agonists resulted in increased ICAM-1 and MCP-1 expression as well as the activation of the NFKB pathway adding further credential to a central role of the Sertoli cells in testicular immunology (Riccioli et al., 2006; Starace et al., 2008).

In our own studies, a comprehensive expression analysis of TLRs and the adaptor molecule MyD88 in rat testicular cells by RT-PCR showed that testicular macrophages and dendritic cells express the mRNAs of all TLRs, while germ cells and somatic cells were usually positive for varying sets of two to three TLRs. Notably, TLR3 expression was most prominent in all testicular cells, except Leydig cells and spermatids, where only 
weak expression was evident (Bhushan et al., 2008). This indicates a strong capacity of recognizing double stranded viral RNA in the testis. These results are largely in agreement with TLR expression in total testis of other species as well as in rat (Nishimura \& Naito, 2005; Rodriguez-Martinez et al., 2005; Palladino et al., 2007), even though we could barely detect TLR4 and TLR6 synthesis in rat Sertoli cell as previously reported for the mouse by Riccioli et al. (Riccioli et al., 2006). The broad distribution of TLRs in the testicular cells indicates that they provide wide range detection of bacteria and viruses and play an important role in the innate immune system of the testis (Figure 1) (Girling \& Hedger, 2007).

\section{Toll like receptor signaling pathways}

The engagement of TLRs by microbial agents activate a common signaling pathway that culminates in the activation of nuclear factor-kB (NFKB) transcription factors, as well as the mitogen-activated protein kinases (MAPKs) extracellular signal regulated kinase (ERK), p38, and c-Jun N-terminal kinase (JNK). TLR ligand binding induces receptor dimerization and conformational changes which are required for the recruitment of the adaptor molecule to the TIR domain. Four TIR domain containing adaptor molecule have been identified to date; i.e. myeloid differentiation primaryresponse protein 88 (MyD88), MyD88 adaptor like protein (MAL), TIR-domain containing adaptor protein inducing IFN $\beta$ (TRIF) and TRIF related adaptor molecule (TRAM) (Oshiumi et al., 2003; Yamamoto et al., 2003). Recently, a fifth adaptor molecule, sterile $\alpha$ and armadillo motif containing protein (SARM) has been identified, which negatively regulates TLR signal transduction (Carty et al., 2006). MyD88 is the key signaling adaptor molecule for all Toll like receptors with the exception of TLR3 and certain TLR4 ligands, which activates signaling through TRIF adaptor molecule. The respective TLRs signaling pathway involved is broadly classified into MyD88 dependent signaling pathway or MyD88 independent signaling pathway (Figure 2).

The MyD88-dependent pathway is similar to IL-1 receptors signaling pathways and the cytoplasmic domain of TLRs and IL-1 receptors share a common region which is 
therefore termed Toll/IL-1 receptor (TIR) domain. The TIR signaling domain is instrumental in TLR signaling as upon binding to the ligand, MyD88 is recruited to the TIR domain of TLRs. MyD88 binding results in a signaling cascade which finally mediates ubiquitination and degradation of $\mathrm{I} \kappa \mathrm{B} \alpha$ via activation of various kinases and other intermediates. Subsequently, NFkB translocates to the nucleus and activates expression of multiple pro-inflammatory cytokines such as archetypical IL-1, IL-6 and TNF $\alpha$ (Figure 2).

To activate the MyD88-independent signaling pathway, the N-terminal region of the TRIF adaptor molecule interacts with the TRAF family-member-associated NF- $\kappa \mathrm{B}$ activator (TANK) binding kinase 1 (TBK1) via TRAF3. Activated TBK1 in concert with

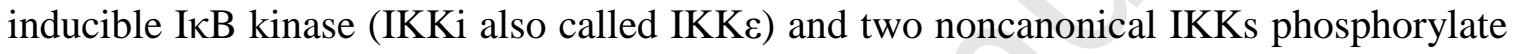
IRF3 (Fitzgerald et al., 2003; Sharma et al., 2003). Phosphorylated IRF3 form homodimers which translocate into the nucleus, resulting in the expression of a set of IFN-inducible genes such as IFN $\alpha / \beta$, IP10 and RANTES (Figure 2).

\section{Impairment of testicular and sperm function by $E$. coli}

The effects of $E$. coli on the male genital tract have been investigated to some extent in experimental and clinical studies. There are several in vivo as well as in vitro studies showing a negative effect of $E$. coli on human sperm function such as motility and acrosome reaction (Auroux et al., 1991; Merino et al., 1995; el-Mulla et al., 1996; Huwe et al., 1998; Kohn et al., 1998; Diemer et al., 2003). A direct inhibitory effect of E. coli on progressive motility was found to depend on bacterial concentration, and analysis by electron microscopy revealed multiple adhesions of $E$. coli to spermatozoa with a variable degree of ultrastructural damage present (Diemer et al., 1996). It has been shown that E. coli attaches to the superficial structures of human spermatozoa via type 1 adhesion molecules present on both bacterial pili and spermatozoa, respectively, that can be inactivated by preincubation with mannose (Wolff et al., 1993; Diemer et al., 1996; Diemer et al., 2000). Bacterial adhesion resulted in ultrastructural alterations and damage of the plasma membrane including the sperm head and acrosome. Defects in the acrosome, the mid piece, and the sperm tail apparently result in diminished motility and impaired fertilizing capacity of the affected gametes (Diemer et al., 2003). Oxidative 
stress and apoptosis of spermatozoa was also observed following incubation with $E$. coli (Villegas et al., 2005; Fraczek et al., 2007). In rat in vivo models the retrograde inoculation of $E$. coli into the vas deferens promoted clinically recognizable acute orchitis characterized by severe degeneration of germinal epithelial cells, tubular atrophy, moderate inflammation and mild interstitial fibrosis with subsequent testicular damage (Demir et al., 2007). These findings are associated with a decrease in testicular volume and sperm concentration in comparison to control testes (Ludwig et al., 2002; Demir et al., 2007).

\section{Uropathogenic E. coli (UPEC) subvert testicular immune response}

Uropathogenic Escherichia coli (UPEC) have been shown to evade host innate immune response by inhibiting NF- $\kappa \mathrm{B}$ activation in testicular cells and urothelial cells ultimately leading to suppression of cytokine secretion (Bhushan et al., 2008; Billips et al., 2008). In clinical UPEC isolates 15 out of 17 strains revealed this ability (Billips et al., 2007). Many studies have shown that virulence factors of pathogens induces NFkB suppression in host cells by targeting multiple signaling pathways and limit the host cell inflammatory responses (Ruckdeschel et al., 2001; Collier-Hyams et al., 2002; Yoshimura et al., 2002). Yersinia pestis injects a virulence factor (YopJ) in the host cell and blocks NFKB activation and MAP kinase signaling by binding and preventing the activation of the upstream MAP kinases (MKKs) and IKK $\beta$ kinases (Orth et al., 1999; Orth et al., 2000). Simultaneously, YopJ can suppress the expression of cytokines while inducing apoptosis during infection. Our work and that of others suggest that UPEC may also produce a virulence factor which is similar to YopJ in its ability to suppress the NFKB signaling pathway. This hypothesis is supported by the fact that the suppressive capability required UPEC to be viable, as heat-killed bacteria failed to suppress epithelial responses (Hunstad et al., 2005).

By using in silico bioinformatics a hitherto uncharacterized open reading frame harbouring a Toll IL1R (TIR) domain has been documented in the UPEC CFT073 genome (Cirl et al., 2008). Further analysis revealed that the TcpC protein encoded in the SerU island of the UPEC strain CFT073 contains a TIR domain in the C-terminal region. 
The TIR domain is universal to TLRs and required for docking of adaptor proteins MyD88, Mal and TRIF to trigger signal transduction such as MAPK activation. Interestingly, during the infection of kidney cells TcpC impaired this TLR signalling pathways by direct binding to MyD88 resulting in suppressed proinflammatory cytokine secretion (Cirl et al., 2008).

Sertoli cells, peritubular cells and testicular macrophages, all centrally implicated in the testicular defense system were found to express TLR4 (Bhushan et al., 2008) (Figure 1). TLR4 is the sensor of LPS, a major component of gram-negative bacteria cell wall. It is therefore surprising that incubation with UPEC or commensal non-pathogenic E. coli (NPEC) did not result in the release of the proinflammatory cytokines IL-1 $\alpha$, IL-6 and TNF $\alpha$ despite of the partial activation of the MyD88-dependent TLR4 signaling pathway which is known to lead to their synthesis. Our data suggest that the lack of proinflammatory cytokine production is likely due to active suppression of the MyD88dependent NFkB pathway by UPEC at various levels of the signaling cascade depending on the cell type infected (Bhushan et al., 2008). All four examined cell types (Sertoli cells, peritubular cells and testicular and peritoneal macrophages, Figure 1) respond to incubation with UPEC, but not with NPEC, with elevated TLR4 protein levels. In peritubular cells and peritoneal macrophages as control downstream signaling after UPEC exposure is initiated as MAP kinases p38 and/or JNK are activated. These two kinases normally trigger transcription of proinflammatory genes including IL-1, IL-6 and TNF $\alpha$ by activation of nuclear transcription factors AP1 and NFAT. Stimulation of MyD88 pathway in peritubular cells and peritoneal macrophages culminates in degradation of $I \kappa B \alpha$ with subsequent transfer of p65 unit of NFKB to the nucleus (Bhushan et al., 2008). In spite of activation of both MAP kinases and NFKB the transcription of proinflammatory genes is blocked. In Sertoli cells and testicular macrophages the MAP kinases are activated, but not the NFאB pathway, thus supporting the observation that lack of proinflammatory cytokine secretion is not related to lack of pathogen recognition, but more likely to virulence factors that block downstream transmission of proinflammatory signals. It seems that in testicular macrophages and Sertoli cells, NFKB activation is already blocked before or at the point of activation of IאB kinases. In PM and PTC however the MyD88 - NFאB dependent cytokine 
production must be abrogated at the start of gene transcription or at the posttranscriptional level (Bhushan et al., 2008).

Further support for an UPEC induced cytokine suppressing mechanism in the testis is derived indirectly from our observation that co-incubation of peritoneal macrophages with UPEC fully inhibited LPS or NPEC induced production of IL-1 $\alpha$, IL-6 and TNF $\alpha$ (Figure 2). Similarly, IL-6 synthesis was found abrogated by UPEC strain UTI89 in bladder epithelial cells (Hunstad et al., 2005) with inhibition of the classical NFkB pathway, albeit without evidence at which point this may occur (Klumpp et al., 2001). Unlike PM, all testicular cells were unresponsive to both LPS and NPEC challenge in terms of IL-1, IL-6 and TNF $\alpha$ secretion, however, we could detect upregulation of MCP1 , TGF $\beta$ and COX-2 at least in TM.

Recent analysis of TLR4 signaling has revealed that LPS can induce a similar response as seen by stimulating TLR3, which senses double stranded viral RNA, by producing type I IFN such as IFN- $\alpha$, IFN- $\beta$ and IFN-response genes like MCP-1, IFN- $\gamma$ inducible protein 10 (IP10) and RANTES (Kawai et al., 2001). This so-called MyD88independent pathway involves another adapter molecule TRIF which activates the TRIFrelated adapter molecule (TRAM), causing phosphorylation of interferon regulated factor (IRF)-3 in infected cells. After transfer to the nucleus phosphorylated IRF-3 induces an antiviral and apoptotic response in various cells that is characterized by the production of endogenous type I IFNs and chemokines (Han et al., 2004; Ruckdeschel et al., 2004; De Trez et al., 2005; Kaiser \& Offermann, 2005; Rasschaert et al., 2005; O'Neill \& Bowie, 2007). This demonstrates that upon initial triggering by a pathogen, anti-viral and antibacterial pathways can merge by using common adapter molecules. In fact, infection of rat testicular somatic cells with Sendai virus, closely related to the mumps virus causing orchitis in humans, resulted in elevated levels of MCP-1, IP10 and IFN $\alpha$ mRNA (Dejucq et al., 1995; Le Goffic et al., 2002), a response very similar to that after UPEC challenge in this study. In the process of investigating a potential activation of the TLR4TRIF/IRF3 pathway we found MyD88 independent nuclear translocation of IRF3 in all testicular cell types after treatment with UPEC, but not with NPEC (Bhushan et al., 2008). Furthermore, upregulation of IP10, RANTES and MCP-1 in peritubular cells as well as of IFN $\alpha / \beta$ and IP10 in testicular macrophages and Sertoli cells clearly indicated that 
UPEC infection fully activated the TRAM-TRIF-IRF-3 alternative pathway resulting in transcription of these genes. This upregulated synthesis of chemokines may provide an explanation for the observed influx of leukocytes in bacterial orchitis (Mukasa et al., 1995).

In summary, UPEC-dependent inhibition of the cellular NFKB pathway suppresses production of proinflammatory cytokines in the testis. However, subsequent inflammation is subverted by effective activation of the MyD88-independent pathway resembling an anti-viral immune response, thus promoting bacterial survival and virulence. In view of the immune privileged status of the testis, this analysis provides mechanistic insight into the process by which cytokine secretion is abrogated at different stages in the signalling pathways in different cell populations of the testis.

\section{Acknowledgements}

The grant support of the Deutsche Forschungsgemeinschaft (Clinical Research Unit KFO 181), the National Genome Research Network (NGFN), Germany (NGFN IES08T03) and the Dr. Heinz-Horst Deichmann Foundation is gratefully acknowledged. 


\section{References:}

Akira S, Takeda K (2004) Toll-like receptor signalling. Nat Rev Immunol 4:499-511.

Akira S, Uematsu S, Takeuchi O (2006) Pathogen recognition and innate immunity. Cell 124:783-801.

Anders HJ, Patole PS (2005) Toll-like receptors recognize uropathogenic Escherichia coli and trigger inflammation in the urinary tract. Nephrol Dial Transplant 20:1529-32.

Applequist SE, Wallin RP, Ljunggren HG (2002) Variable expression of Toll-like receptor in murine innate and adaptive immune cell lines. Int Immunol 14:1065-74.

Auroux MR, Jacques L, Mathieu D, Auer J (1991) Is the sperm bacterial ratio a determining factor in impairment of sperm motility: an in-vitro study in man with Escherichia coli. Int J Androl 14:264-70.

Beutler B (2004) Inferences, questions and possibilities in Toll-like receptor signalling. Nature 430:257-63.

Bhushan S, Tchatalbachev S, Klug J, Fijak M, Pineau C, Chakraborty T, Meinhardt A (2008) Uropathogenic Escherichia coli Block MyD88-Dependent and Activate MyD88Independent Signaling Pathways in Rat Testicular Cells. J Immunol 180:5537-47.

Billips BK, Forrestal SG, Rycyk MT, Johnson JR, Klumpp DJ, Schaeffer AJ (2007) Modulation of host innate immune response in the bladder by uropathogenic Escherichia coli. Infect Immun 75:5353-60.

Billips BK, Schaeffer AJ, Klumpp DJ (2008) The Molecular Basis of Uropathogenic Escherichia coli Evasion of the Innate Immune Response in the Bladder. Infect Immun.

Blum G, Ott M, Lischewski A, Ritter A, Imrich H, Tschape H, Hacker J (1994) Excision of large DNA regions termed pathogenicity islands from tRNA-specific loci in the chromosome of an Escherichia coli wild-type pathogen. Infect Immun 62:606-14.

Bowie A, O'Neill LA (2000) The interleukin-1 receptor/Toll-like receptor superfamily: signal generators for pro-inflammatory interleukins and microbial products. J Leukoc Biol 67:508-14.

Brzuszkiewicz E, Bruggemann H, Liesegang H, Emmerth M, Olschlager T, Nagy G, Albermann K, Wagner C, Buchrieser C, Emody L, Gottschalk G, Hacker J, Dobrindt U (2006) How to become a uropathogen: comparative genomic analysis of extraintestinal pathogenic Escherichia coli strains. Proc Natl Acad Sci U S A 103:12879-84.

Carty M, Goodbody R, Schroder M, Stack J, Moynagh PN, Bowie AG (2006) The human adaptor SARM negatively regulates adaptor protein TRIF-dependent Toll-like receptor signaling. Nat Immunol 7:1074-81. 
Cirl C, Wieser A, Yadav M, Duerr S, Schubert S, Fischer H, Stappert D, Wantia N, Rodriguez N, Wagner H, Svanborg C, Miethke T (2008) Subversion of Toll-like receptor signaling by a unique family of bacterial Toll/interleukin-1 receptor domain-containing proteins. Nat Med 14:399-406.

Collier-Hyams LS, Zeng H, Sun J, Tomlinson AD, Bao ZQ, Chen H, Madara JL, Orth K, Neish AS (2002) Cutting edge: Salmonella AvrA effector inhibits the key proinflammatory, anti-apoptotic NF-kappa B pathway. J Immunol 169:2846-50.

Collins MM, Stafford RS, O'Leary MP, Barry MJ (1998) How common is prostatitis? A national survey of physician visits. J Urol 159:1224-8.

De Trez C, Pajak B, Brait M, Glaichenhaus N, Urbain J, Moser M, Lauvau G, Muraille E (2005) TLR4 and Toll-IL-1 receptor domain-containing adapter-inducing IFN-beta, but not MyD88, regulate Escherichia coli-induced dendritic cell maturation and apoptosis in vivo. J Immunol 175:839-46.

Dejucq N, Dugast I, Ruffault A, van der Meide PH, Jegou B (1995) Interferon-alpha and -gamma expression in the rat testis. Endocrinology 136:4925-31.

Demir A, Turker P, Onol FF, Sirvanci S, Findik A, Tarcan T (2007) Effect of experimentally induced Escherichia coli epididymo-orchitis and ciprofloxacin treatment on rat spermatogenesis. Int J Urol 14:268-72.

Diemer T, Huwe P, Ludwig M, Schroeder-Printzen I, Michelmann HW, Schiefer HG, Weidner W (2003) Influence of autogenous leucocytes and Escherichia coli on sperm motility parameters in vitro. Andrologia 35:100-5.

Diemer T, Huwe P, Michelmann HW, Mayer F, Schiefer HG, Weidner W (2000) Escherichia coli-induced alterations of human spermatozoa. An electron microscopy analysis. Int J Androl 23:178-86.

Diemer T, Weidner W, Michelmann HW, Schiefer HG, Rovan E, Mayer F (1996) Influence of Escherichia coli on motility parameters of human spermatozoa in vitro. Int J Androl 19:271-7.

Dobrindt U, Blum-Oehler G, Nagy G, Schneider G, Johann A, Gottschalk G, Hacker J (2002) Genetic structure and distribution of four pathogenicity islands (PAI I(536) to PAI IV(536)) of uropathogenic Escherichia coli strain 536. Infect Immun 70:6365-72.

Dobrindt U, Hochhut B, Hentschel U, Hacker J (2004) Genomic islands in pathogenic and environmental microorganisms. Nat Rev Microbiol 2:414-24.

Dohle GR, Colpi GM, Hargreave TB, Papp GK, Jungwirth A, Weidner W (2005) EAU guidelines on male infertility. Eur Urol 48:703-11. 
Eisenstein BI, Jones GW (1988) The spectrum of infections and pathogenic mechanisms of Escherichia coli. Adv Intern Med 33:231-52.

el-Mulla KF, Kohn FM, Dandal M, el Beheiry AH, Schiefer HG, Weidner W, Schill WB (1996) In vitro effect of Escherichia coli on human sperm acrosome reaction. Arch Androl 37:73-8.

Fijak M, Meinhardt A (2006) The testis in immune privilege. Immunol Rev 213:66-81.

Filippini A, Riccioli A, Padula F, Lauretti P, D'Alessio A, De Cesaris P, Gandini L, Lenzi A, Ziparo E (2001) Control and impairment of immune privilege in the testis and in semen. Hum Reprod Update 7:444-9.

Fitzgerald KA, McWhirter SM, Faia KL, Rowe DC, Latz E, Golenbock DT, Coyle AJ, Liao SM, Maniatis T (2003) IKKepsilon and TBK1 are essential components of the IRF3 signaling pathway. Nat Immunol 4:491-6.

Fraczek M, Szumala-Kakol A, Jedrzejczak P, Kamieniczna M, Kurpisz M (2007) Bacteria trigger oxygen radical release and sperm lipid peroxidation in in vitro model of semen inflammation. Fertil Steril 88:1076-85.

Girling JE, Hedger MP (2007) Toll-like receptors in the gonads and reproductive tract: emerging roles in reproductive physiology and pathology. Immunol Cell Biol 85:481-9.

Guyer DM, Kao JS, Mobley HL (1998) Genomic analysis of a pathogenicity island in uropathogenic Escherichia coli CFT073: distribution of homologous sequences among isolates from patients with pyelonephritis, cystitis, and Catheter-associated bacteriuria and from fecal samples. Infect Immun 66:4411-7.

Hacker J, Hentschel U, Dobrindt U (2003) Prokaryotic chromosomes and disease. Science 301:790-3.

Hacker J, Knapp S, Goebel W (1983) Spontaneous deletions and flanking regions of the chromosomally inherited hemolysin determinant of an Escherichia coli O6 strain. J Bacteriol 154:1145-52.

Haidl G, Allam JP, Schuppe HC (2008) Chronic epididymitis: impact on semen parameters and therapeutic options. Andrologia 40:92-6.

Han KJ, Su X, Xu LG, Bin LH, Zhang J, Shu HB (2004) Mechanisms of the TRIFinduced interferon-stimulated response element and NF-kappaB activation and apoptosis pathways. J Biol Chem 279:15652-61. 
Hashimoto C, Hudson KL, Anderson KV (1988) The Toll gene of Drosophila, required for dorsal-ventral embryonic polarity, appears to encode a transmembrane protein. Cell 52:269-79.

Head JR, Neaves WB, Billingham RE (1983) Immune privilege in the testis. I. Basic parameters of allograft survival. Transplantation 36:423-31.

Hedger MP, Meinhardt A (2003) Cytokines and the immune-testicular axis. J Reprod Immunol 58:1-26.

Hunstad DA, Justice SS, Hung CS, Lauer SR, Hultgren SJ (2005) Suppression of bladder epithelial cytokine responses by uropathogenic Escherichia coli. Infect Immun 73:39994006.

Huwe P, Diemer T, Ludwig M, Liu J, Schiefer HG, Weidner W (1998) Influence of different uropathogenic microorganisms on human sperm motility parameters in an in vitro experiment. Andrologia 30 Suppl 1:55-9.

Johnson JR (1991) Virulence factors in Escherichia coli urinary tract infection. Clin Microbiol Rev 4:80-128.

Johnson JR, Kuskowski M (2000) Clonal origin, virulence factors, and virulence. Infect Immun 68:424-5.

Johnson JR, Russo TA (2005) Molecular epidemiology of extraintestinal pathogenic (uropathogenic) Escherichia coli. Int J Med Microbiol 295:383-404.

Johnson JR, Stell AL (2000) Extended virulence genotypes of Escherichia coli strains from patients with urosepsis in relation to phylogeny and host compromise. J Infect Dis 181:261-72.

Kaiser WJ, Offermann MK (2005) Apoptosis induced by the toll-like receptor adaptor TRIF is dependent on its receptor interacting protein homotypic interaction motif. $\mathrm{J}$ Immunol 174:4942-52.

Kao JS, Stucker DM, Warren JW, Mobley HL (1997) Pathogenicity island sequences of pyelonephritogenic Escherichia coli CFT073 are associated with virulent uropathogenic strains. Infect Immun 65:2812-20.

Kawai T, Takeuchi O, Fujita T, Inoue J, Muhlradt PF, Sato S, Hoshino K, Akira S (2001) Lipopolysaccharide stimulates the MyD88-independent pathway and results in activation of IFN-regulatory factor 3 and the expression of a subset of lipopolysaccharide-inducible genes. J Immunol 167:5887-94. 
Klumpp DJ, Weiser AC, Sengupta S, Forrestal SG, Batler RA, Schaeffer AJ (2001) Uropathogenic Escherichia coli potentiates type 1 pilus-induced apoptosis by suppressing NF-kappaB. Infect Immun 69:6689-95.

Kohn FM, Erdmann I, Oeda T, el Mulla KF, Schiefer HG, Schill WB (1998) Influence of urogenital infections on sperm functions. Andrologia 30 Suppl 1:73-80.

Krieger JN (1984) Epididymitis, orchitis, and related conditions. Sex Transm Dis 11:17381.

Le Goffic R, Mouchel T, Aubry F, Patard JJ, Ruffault A, Jegou B, Samson M (2002) Production of the chemokines monocyte chemotactic protein-1, regulated on activation normal $\mathrm{T}$ cell expressed and secreted protein, growth-related oncogene, and interferongamma-inducible protein-10 is induced by the Sendai virus in human and rat testicular cells. Endocrinology 143:1434-40.

Lemaitre B, Nicolas E, Michaut L, Reichhart JM, Hoffmann JA (1996) The dorsoventral regulatory gene cassette spatzle/Toll/cactus controls the potent antifungal response in Drosophila adults. Cell 86:973-83.

Ludwig M (2008) Diagnosis and therapy of acute prostatitis, epididymitis and orchitis. Andrologia 40:76-80.

Ludwig M, Johannes S, Bergmann M, Failing K, Schiefer HG, Weidner W (2002) Experimental Escherichia coli epididymitis in rats: a model to assess the outcome of antibiotic treatment. BJU Int 90:933-8.

Ludwig M, Velcovsky HG, Weidner W (2008) Tuberculous epididymo-orchitis and prostatitis: a case report. Andrologia 40:81-3.

Merino G, Carranza-Lira S, Murrieta S, Rodriguez L, Cuevas E, Moran C (1995) Bacterial infection and semen characteristics in infertile men. Arch Androl 35:43-7.

Mobley HL, Green DM, Trifillis AL, Johnson DE, Chippendale GR, Lockatell CV, Jones BD, Warren JW (1990) Pyelonephritogenic Escherichia coli and killing of cultured human renal proximal tubular epithelial cells: role of hemolysin in some strains. Infect Immun 58:1281-9.

Mukasa A, Hiromatsu K, Matsuzaki G, O'Brien R, Born W, Nomoto K (1995) Bacterial infection of the testis leading to autoaggressive immunity triggers apparently opposed responses of alpha beta and gamma delta T cells. J Immunol 155:2047-56.

Nickel JC, Siemens DR, Nickel KR, Downey J (2002) The patient with chronic epididymitis: characterization of an enigmatic syndrome. J Urol 167:1701-4. 
Nieschlag E, Behre HM (2000) Andrology. Male Reproductive Health and Dysfunction. 2nd ed ed. Springer, Berlin.

Nishimura M, Naito S (2005) Tissue-specific mRNA expression profiles of human tolllike receptors and related genes. Biol Pharm Bull 28:886-92.

O'Neill LA, Bowie AG (2007) The family of five: TIR-domain-containing adaptors in Toll-like receptor signalling. Nat Rev Immunol 7:353-64.

Ochsendorf FR (2008) Sexually transmitted infections: impact on male fertility. Andrologia 40:72-5.

Orth K, Palmer LE, Bao ZQ, Stewart S, Rudolph AE, Bliska JB, Dixon JE (1999) Inhibition of the mitogen-activated protein kinase kinase superfamily by a Yersinia effector. Science 285:1920-3.

Orth K, Xu Z, Mudgett MB, Bao ZQ, Palmer LE, Bliska JB, Mangel WF, Staskawicz B, Dixon JE (2000) Disruption of signaling by Yersinia effector YopJ, a ubiquitin-like protein protease. Science 290:1594-7.

Osegbe DN (1991) Testicular function after unilateral bacterial epididymo-orchitis. Eur Urol 19:204-8.

Oshiumi H, Matsumoto M, Funami K, Akazawa T, Seya T (2003) TICAM-1, an adaptor molecule that participates in Toll-like receptor 3-mediated interferon-beta induction. Nat Immunol 4:161-7.

Palladino MA, Johnson TA, Gupta R, Chapman JL, Ojha P (2007) Members of the Tolllike receptor family of innate immunity pattern-recognition receptors are abundant in the male rat reproductive tract. Biol Reprod 76:958-64.

Purvis K, Christiansen E (1993) Infection in the male reproductive tract. Impact, diagnosis and treatment in relation to male infertility. Int J Androl 16:1-13.

Rasko DA, Phillips JA, Li X, Mobley HL (2001) Identification of DNA sequences from a second pathogenicity island of uropathogenic Escherichia coli CFT073: probes specific for uropathogenic populations. J Infect Dis 184:1041-9.

Rasschaert J, Ladriere L, Urbain M, Dogusan Z, Katabua B, Sato S, Akira S, Gysemans C, Mathieu C, Eizirik DL (2005) Toll-like receptor 3 and STAT-1 contribute to doublestranded RNA+ interferon-gamma-induced apoptosis in primary pancreatic beta-cells. $\mathrm{J}$ Biol Chem 280:33984-91.

Riccioli A, Starace D, Galli R, Fuso A, Scarpa S, Palombi F, De Cesaris P, Ziparo E, Filippini A (2006) Sertoli cells initiate testicular innate immune responses through TLR activation. J Immunol 177:7122-30. 
Rodriguez-Martinez S, Cancino-Diaz ME, Jimenez-Zamudio L, Garcia-Latorre E, Cancino-Diaz JC (2005) TLRs and NODs mRNA expression pattern in healthy mouse eye. Br J Ophthalmol 89:904-10.

Ruckdeschel K, Mannel O, Richter K, Jacobi CA, Trulzsch K, Rouot B, Heesemann J (2001) Yersinia outer protein $\mathrm{P}$ of Yersinia enterocolitica simultaneously blocks the nuclear factor-kappa B pathway and exploits lipopolysaccharide signaling to trigger apoptosis in macrophages. J Immunol 166:1823-31.

Ruckdeschel K, Pfaffinger G, Haase R, Sing A, Weighardt H, Hacker G, Holzmann B, Heesemann J (2004) Signaling of apoptosis through TLRs critically involves toll/IL-1 receptor domain-containing adapter inducing IFN-beta, but not MyD88, in bacteriainfected murine macrophages. J Immunol 173:3320-8.

Russo TA, Johnson JR (2000) Proposal for a new inclusive designation for extraintestinal pathogenic isolates of Escherichia coli: ExPEC. J Infect Dis 181:1753-4.

Schneider G, Dobrindt U, Bruggemann H, Nagy G, Janke B, Blum-Oehler G, Buchrieser C, Gottschalk G, Emody L, Hacker J (2004) The pathogenicity island-associated K15 capsule determinant exhibits a novel genetic structure and correlates with virulence in uropathogenic Escherichia coli strain 536. Infect Immun 72:5993-6001.

Schuppe HC, Meinhardt A (2005) Immune privilege and inflammation of the testis. Chem Immunol Allergy 88:1-14.

Schuppe HC, Meinhardt A, Allam JP, Bergmann M, Weidner W, Haidl G (2008) Chronic orchitis: a neglected cause of male infertility? Andrologia 40:84-91.

Sharma S, tenOever BR, Grandvaux N, Zhou GP, Lin R, Hiscott J (2003) Triggering the interferon antiviral response through an IKK-related pathway. Science 300:1148-51.

Slack JL, Schooley K, Bonnert TP, Mitcham JL, Qwarnstrom EE, Sims JE, Dower SK (2000) Identification of two major sites in the type I interleukin-1 receptor cytoplasmic region responsible for coupling to pro-inflammatory signaling pathways. J Biol Chem 275:4670-8.

Stamm WE, Norrby SR (2001) Urinary tract infections: disease panorama and challenges. J Infect Dis 183 Suppl 1:S1-4.

Starace D, Galli R, Paone A, De Cesaris P, Filippini A, Ziparo E, Riccioli A (2008) TollLike Receptor 3 Activation Induces Antiviral Immune Responses in Mouse Sertoli Cells. Biol Reprod. 
Swenson DL, Bukanov NO, Berg DE, Welch RA (1996) Two pathogenicity islands in uropathogenic Escherichia coli J96: cosmid cloning and sample sequencing. Infect Immun 64:3736-43.

Villegas J, Schulz M, Soto L, Sanchez R (2005) Bacteria induce expression of apoptosis in human spermatozoa. Apoptosis 10:105-10.

Weidner W, Colpi GM, Hargreave TB, Papp GK, Pomerol JM, Ghosh C (2002) EAU guidelines on male infertility. Eur Urol 42:313-22.

Weidner W, Garbe C, Weissbach L, Harbrecht J, Kleinschmidt K, Schiefer HG, Friedrich HJ (1990) [Initial therapy of acute unilateral epididymitis using ofloxacin. II. Andrological findings]. Urologe A 29:277-80.

Weidner W, Krause W, Ludwig M (1999) Relevance of male accessory gland infection for subsequent fertility with special focus on prostatitis. Hum Reprod Update 5:421-32.

Welch RA, Burland V, Plunkett G, 3rd, Redford P, Roesch P, Rasko D, Buckles EL, Liou SR, Boutin A, Hackett J, Stroud D, Mayhew GF, Rose DJ, Zhou S, Schwartz DC, Perna NT, Mobley HL, Donnenberg MS, Blattner FR (2002) Extensive mosaic structure revealed by the complete genome sequence of uropathogenic Escherichia coli. Proc Natl Acad Sci U S A 99:17020-4.

WHO (1987) Towards more objectivity in diagnosis and managment of male infertility. Int J Androl Suppl 7.

Wiles TJ, Kulesus RR, Mulvey MA (2008) Origins and virulence mechanisms of uropathogenic Escherichia coli. Exp Mol Pathol 85:11-9.

Wolff H, Panhans A, Stolz W, Meurer M (1993) Adherence of Escherichia coli to sperm: a mannose mediated phenomenon leading to agglutination of sperm and E. coli. Fertil Steril 60:154-8.

Yamamoto M, Sato S, Hemmi H, Uematsu S, Hoshino K, Kaisho T, Takeuchi O, Takeda $\mathrm{K}$, Akira S (2003) TRAM is specifically involved in the Toll-like receptor 4-mediated MyD88-independent signaling pathway. Nat Immunol 4:1144-50.

Yoshimura A, Kaneko T, Kato Y, Golenbock DT, Hara Y (2002) Lipopolysaccharides from periodontopathic bacteria Porphyromonas gingivalis and Capnocytophaga ochracea are antagonists for human toll-like receptor 4. Infect Immun 70:218-25. 


\section{Legend Figure 1}

Simplified schematic representation of the testicular immune environment. A crosssection of the seminiferous epithelium consisting of Sertoli cells (SC) and germ cells (GC) with surrounding peritubular cells (PTC) is visible. The adjacent interstitial tissue contains the testicular leukocytes, amongst which monocytes/macrophages (MФ) are the most abundant immune cell type followed by T cells and NK cells. Mast cells (MC) are found in rodents only in small numbers under the capsule, but are more frequent in human where they are interspersed throughout the interstitial space. Dendritic cells (DC) together with monocytes/macrophages serve as 'professional' antigen-presenting cells which can incorporate and process antigen for presentation to CD4+ regulatory or 'helper' T cells. Bacterial infections are usually ascending canalicular reproductive tract infections. Within the lumen of the seminiferous epithelium bacterial pathogens are in direct contact to haploid germ cells and Sertoli cells. During infection bacteria can pass through the blood-testis barrier (BTB) or intracellularly and reach the PTC and interstitial cells. Binding of conserved microbial molecular patterns such as lipopolysaccharide to Toll like receptors triggers the innate immune response.

\section{Legend Figure 2}

Simplified model of the Toll-like receptor 4 (TLR4) signalling pathway. Bacterial lipopolysaccharide (LPS) triggers common TLR signaling through an adaptor protein, myeloid differentiation primary response gene 88 (MyD88), that recruits other intermediate molecules, which in term activate mitogen activated protein (MAP) kinases such as p38, JNK and ERK1/2. Furthermore, NFKB is translocated to the nucleus, where it directs transcription of the TLR-response cytokines IL-1, IL-6, TNF $\alpha$. In addition to the common MyD88-dependent pathway, TLR 3 and TLR4 can utilize an alternative MyD88-independent signaling pathway where nuclear translocation of the transcription factor IFN-regulated factor (IRF-3) activates the expression of genes typical for anti-viral responses such as interferon (IFN) $\alpha / \beta$ and interferon $\gamma$ induced protein (IP)-10. $\mathrm{UPEC}=$ uropathogenic $\mathrm{E}$. coli. 


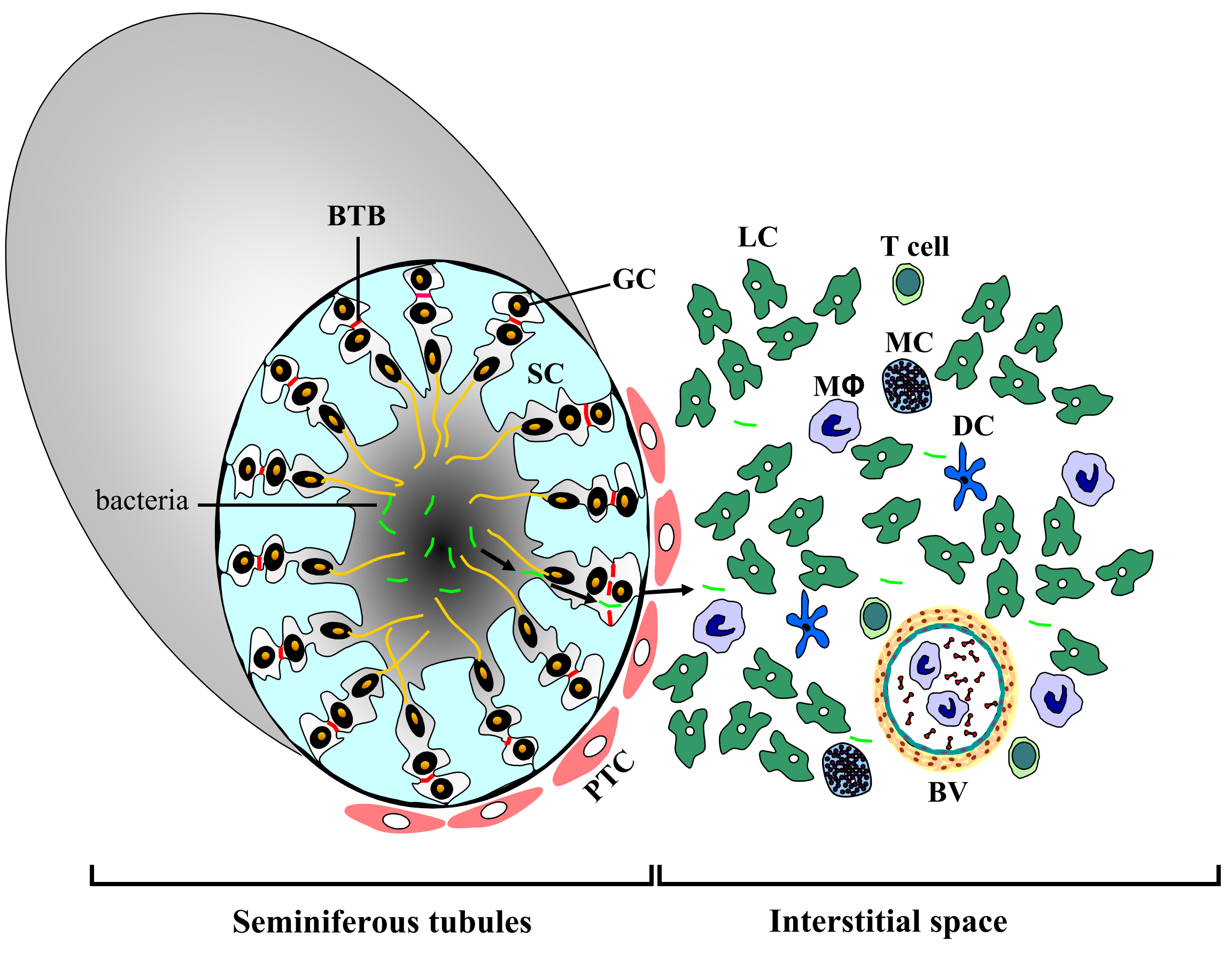




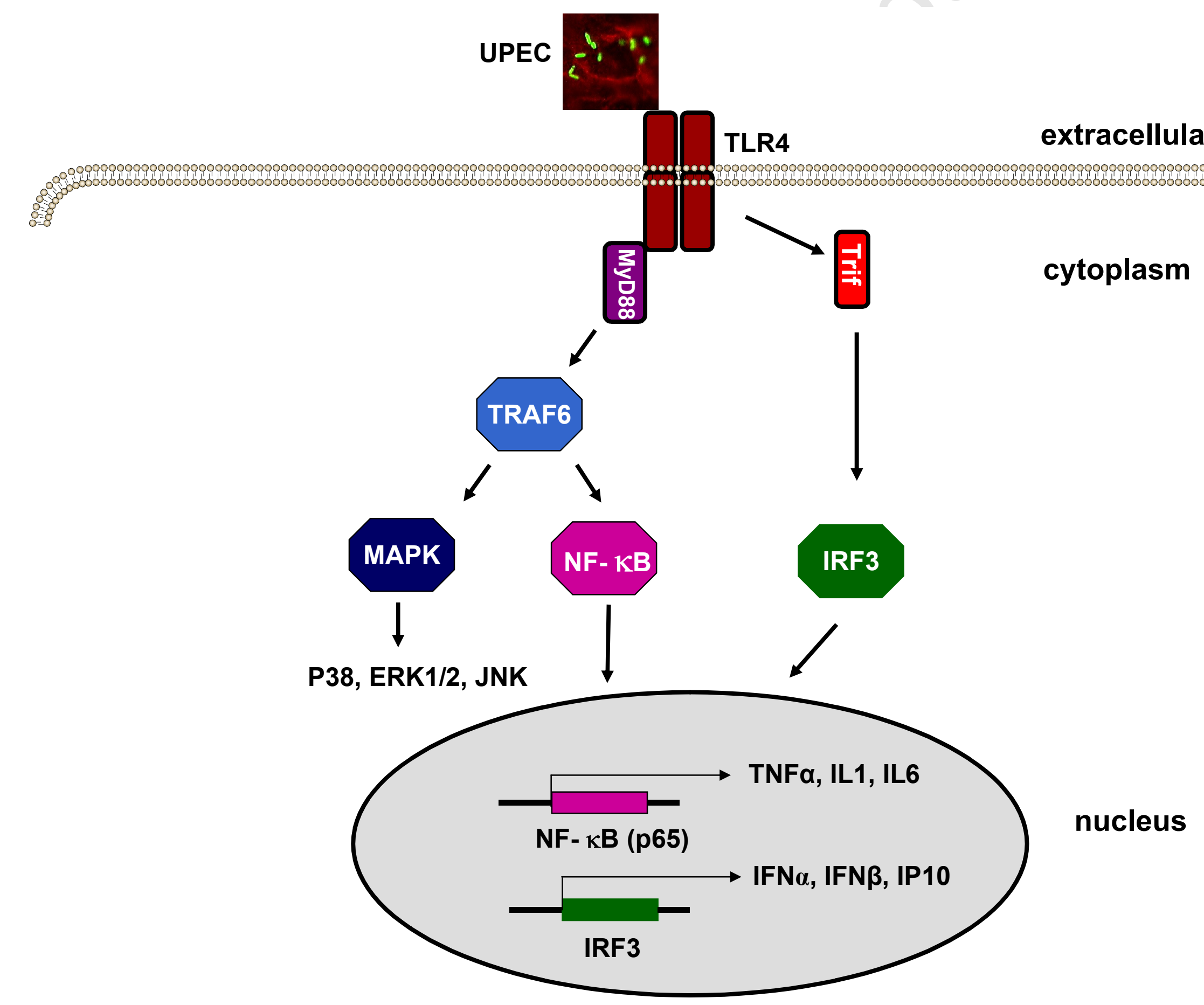

